\title{
Implementasi Sistem Pembayaran Quick Response Indonesia Standard \\ Bagi Perkembangan UMKM di Medan
}

\author{
Josef Evan Sihaloho ${ }^{(1)}$ \\ Atifah Ramadani ${ }^{(2)}$ \\ Suci Rahmayanti ${ }^{(3)}$ \\ Universitas Sumatera Utara $^{(1)(2)(3)}$ \\ sihalohojosef@gmail.com ${ }^{(1)}$ \\ atifahramadani07@ gmail.com ${ }^{(2)}$ \\ surahyaa31@gmail.com ${ }^{(3)}$
}

\begin{abstract}
The use of server-based electronic money is one of the most popular non-cash payment systems in use today. The form of server-based electronic money is e-wallet / digital wallet. E-wallet can be used to transact by customers, if the merchant provides an application Same e-wallet to customers. This made Bank Indonesia, as the regulator of the payment system, issue a new payment channel namely; QRIS (QR Code Indonesia Standard). The use of QRIS is used to standardize all e-wallets applications that use the $Q R$ Code system to conduct payment transactions. This study examines how the application of QRIS to UMKM in Medan, and describes the roles, constraints, and income of UMKM s in the presence of QRIS. The research method used is interviews and literature studies with UMKM traders who have used QRIS as a payment tool in their characters. This research indicates that QRIS has benefits for UMKM traders.
\end{abstract}

Keywords : E- money Server; QR Code; QRIS; UMKM traders

\begin{abstract}
ABSTRAK
Penggunan uang elektronik berbasis server menjadi salah satu sistem pembayaran non- tunai yang sangat popular digunakan saat ini. Wujud uang elektronik berbasis server adalah $e-$ wallet / dompet digital. E-wallet dapat digunakan untuk bertransaksi oleh pelanggan, apabila pedagang (merchant) menyediakan aplikasi $e$ - wallet yang sama pada pelanggan. Hal ini membuat Bank Indonesia sebagai pengatur sistem pembayaran mengeluarkan sebuah sistem pembayaran yang baru yaitu ; QRIS (QR Code Indonesia Standard). Penggunan QRIS digunakan untuk menstandarisasi seluruh aplikasi $e$-wallet yang menggunakan sistem QR Code untuk melakukan transaksi pembayaran. Penelitian ini mengkaji bagaimana penerapan QRIS pada UMKM di Medan, dan memaparkan peranan, kendala, dan pendapatan UMKM dengan adanya QRIS.Metode penelitian yang digunakan adalah wawancara dan studi pustaka dengan para pedagang UMKM yang telah menggunakan QRIS sebagai alat pembayaran di tokohnya. Penelitian ini mengindikasikan bahwa QRIS mempunyai manfaat bagi para pedagang UMKM.
\end{abstract}

Kata kunci: : Uang elektronik berbasis server; QR Code; QRIS; pedagang UMKM 


\section{PENDAHULUAN}

Perkembangan teknologi dan informasi yang maju akan membantu pertumbuhan ekonomi digital dan percepatan inklusi keuangan suatu negara. Salah satu bentuk pengimplementasian antara teknologi -infomasi dengan pertumbuhan ekonomi digital adalah pembayaran transaksi secara non - tunai. Menurut data laporan Bank Indonesia ada 48 penyellengara jasa sistem pembayaran yang telah memperoleh persetujuan untuk melakukan kegiataan transaksi secara non - tunai. Ada 14 dari pihak perbankan dan 34 pihak nonperbankan.Bentuk - bentuk inovasi pada sistem pembayaran non - tunai adalah kartu debit / ATM , kartu kredit ,wesel, cek, bank account dan uang elektronik. Berdasarkan data dari Bank Indonesia di tahun 2019, pemegang tren pembayaran non- tunai adalah uang elektronik sebanyak 95,75 triliun yang telah meningkat dari tahun sebelumnya (2018) dengan transaksi 60,00 triliun. Tingginya angka penggunaan uang elektronik untuk pembayaran non- tunai disebabkan banyaknya produk uang elektronik yang diterbitkan berupa ; kartu $e$-money yang berbasis chip dan berbasis server, seperti :aplikasi $e$-wallet, bank account.

Implementasi uang elektronik yang telah digunakan untuk pembayaran secara online maupun offline dapat memudahkan para pedagang untuk bertransaksi, khususnya UMKM. Adanya kerjasama antara para UMKM dengan pihak penyelenggara uang elektronik akan meningkatkan keuangan inklusif serta memajukan perekonomian Indonesia. Menurut Kementerian Koperasi dan Kecil dan Menengah bahwa jumlah perkembangan pedagang UMKM mengalami peningkatan setiap tahunnya, dapat dilihat pada tabel.

\begin{tabular}{|l|l|l|l|l|}
\hline Jenis Usaha & $\mathbf{2 0 1 7}$ (Unit) & $\mathbf{2 0 1 8}$ (Unit) & $\begin{array}{l}\mathbf{2 0 1 7}-2018 \\
\text { (unit) }\end{array}$ & $\begin{array}{l}\mathbf{2 0 1 7 - 2 0 1 8} \\
(\%)\end{array}$ \\
\hline $\begin{array}{l}\text { Usaha Mikro } \\
\text { (UMi) }\end{array}$ & 62.106 .900 & 63.350 .222 & 1.243 .322 & 2,00 \\
\hline $\begin{array}{l}\text { Usaha Kecil } \\
\text { (UK) }\end{array}$ & 757.090 & 783.132 & 26.043 & 3,44 \\
\hline $\begin{array}{l}\text { Usaha } \\
\text { Menengah } \\
\text { (UM) }\end{array}$ & 58.627 & 60.702 & 2.075 & 3,54 \\
\hline
\end{tabular}

Sumber data dan diolah : Kementerian Koperasi dan Kecil dan Menengah

Banyaknya produk uang elektronik dan diiringi perkembangan UMKM yang begitu pesat, akan memberikan kemudahan bagi para UMKM untuk melakukan transaksi dan juga para pelanggannya. Keuntungan dari adanya uang elektronik ini memudahkan para UMKM untuk tidak kesulitan mencari uang kembalian kepada pelanggan dan pihak pelanggan tidak perlu membawa banyak uang kartal ketika berbelanja. 
Hanya saja produk produk uang elektronik ini dapat digunakan oleh pelanggan ketika produk uang elektronik itu telah tersedia di tokoh pedagang tersebut. Pada penggunaan uang elektronik yang berbasis chip, pedagang harus menyediakan mesin EDC untuk dapat bertransaksi non - tunai dan penggunaan uang elektronik yang berbasis server dilakukan dengan menginstall aplikasi-aplikasi pembayaran pada smartphone.Walaupun penggunaan uang elektronik mempercepat transaksi, tetapi masih kurang efisien dalam penggunaannya.

Menurut data survei APJII (Asosiasi Penyelenggara Jasa Internet Indonesia)dan BPS(Badan Pusat Statistik) bahwa pada tahun 2018 terdapat 171,17 juta $(64,8 \%)$ pengguna internet di Indonesia dari 264,161 juta jumlah penduduk Indonesia.Data survei APJII 2018 mengungkapkan juga bahwa salah satu perangkat yang sering digunakan untuk terhubung dengan internet adalah smartphone, sebesar 93,9\% setiap hari digunakan.Dengan berkembangnya penggunaan internet melalui smartphone, membuat instrumen pembayaran non tunai yang berbasis server lebih banyak digunakan di masyarakat. Data Bank Indonesia pada Maret 2020, ada sebanyak 40 perusahaan telah menerbitkan uang elektronik server. Hal ini menjadi beberapa alasan juga bahwa penggunaan aplikasi - aplikasi $e-$ wallet di pelanggan lebih dominan dan para pedagang telah menyediakan banyak QR Code yang dapat digunakan untuk sistem pembayaran berbasis server,seperti $e$-wallet.Hal ini membuat Bank Indonesia sebagai pengatur sistem pembayaran di Indonesia, pada Agustus 2019 telah meluncurkan kanal pembayaran yang berbasis shared delivery channel untuk instrumen pembayaran yang berbasis server yaitu QUICK RESPONSE INDONESIA STANDARD (QRIS). Kanal pembayaran ini digunakan untuk menstandarisasi seluruh pembayaran non - tunai yang menggunakan QR Code. Salah satu alasan peluncuran kanal pembayaran ini diadakan karena para pedagang di pasar ketika dalam bertransaksi non - tunai harus menyediakan banyak QR Code dari berbagai penerbit. Penggunaan QRIS ini dapat digunakan pada aplikasi - aplikasi pembayaran yang telah terinstall di smartphone yang telah terhubung dengan koneksi internet. Aplikasi - aplikasi yang dimaksud ; e-wallet (dari penerbit perbankan maupun non perbankan) yang digunakan sebagai instrumen pembayaran berbasis server dan telah mendapatkan izin dari Bank Indonesia.Sementara waktu, Bank Indonesia masih mengeluarkan QRIS yang bermode Merchant Payment Mode. QRIS tersebut dapat di-scan oleh pelanggan dengan berbagai jenis aplikasi pembayaran dan pedagang hanya menyediakan satu QR Code di tokohnya sehingga semua aplikasi pembayaran dapat men-scan QR Code tersebut ketika bertransaksi.Dengan adanya sistem pembayaran QRIS yang telah dikeluarkan Bank Indonesia, maka dapat diberikan penelitian untuk menilai keefisienan dari QRIS terhadap perkembangan UMKM. 


\section{DIGITAL PAYMENT}

Digital payment adalah pembayaran digital yang memiliki dua bentuk yaitu dengan menggunakan jaringan komputer dan secara digital (Yuanita Puspita, 2019). Penggunaan uang elektronik dapat terjadi apabila komponen tersebut tersedia pada pemberi dan penerima uang yang dilakukan secara digital. Ada 2 jenis uang elektronik yang dapat ditinjau dari medianya (Dien, 2018).

\section{Uang elektronik yang berbasis chip}

Ciri- ciri:

- Uang elektronik berbasis chip ini dapat menampung nominal uang pada kartu. • Transaksi dilakukan secara offline.

- Uang Elektronik ini dapat digunakan untuk melakukan pembayaran transaksi dalam bentuk massal, seperti pembayaran tol.

\section{Uang elektronik yang berbasis server}

Ciri - ciri :

- Uang elektronik berbasis server dapat menyimpan nominal uang pada aplikasi atau server yang menerbitkan.

- Penggunannya harus dilakukan dengan online.

- Pembayaran dilakukan untuk transkasi dalam nominal kecil

Kanal pembayaran pada uang elektronik berbasis chip bersifat shared delivery channel. Wujud kanal pembayaran tersebut : mesin ATM, mesin EDC, dan QR Code. Sedagnkan kanal pembayaran pada uang elektronik berbasis server bersifat proprietary delivery channel.Wujud kanal pembayarannya : mobile banking dan internet banking.

\section{QR CODE PAYMENT}

QR Code Payment adalah sebuah mekanisme dalam melakukan transfer pembayaran non tunai dan hanya perlu memindai kode QR dari pedagang dan melakukan transfer pembayaran (Dorothy Sagayarani, 2017; Arianti et al., 2019). QR Code dapat dipindai atau discan dari berbagai arah, baik secara horizontal maupun vertikal.

QR Code yang digunakan untuk sistem pembayaran, telah banyak diterbitkan oleh lembaga perbankan dan lembaga non perbankan. Penggunaan QR Code ini diterapkan oleh para pedagang untuk memudahkan sistem pembayaran secara non - tunai yang berbasis server. 
Para pedagang banyak menyediakan QR Code di tokohnya, supaya penggunaannya dapat membantu pelanggan untuk bertransaksi menggunakan QR Code.

\section{QRIS ( QR Code Indonesia Standard )}

QRIS (QR Code Indonesia Standard) adalah sistem pembayaran yang berbasis shared delivery channel yang digunakan untuk menstandarisasi transaksi pembayaran yang menggunakan QR Code. Sistem tersebut diperintis oleh Bank Indonesia dan Asosiasi Sistem Pembayaran Indonesia (ASPI) .Standar Internasional EMV Co ( Europe MasterCard Visa) digunakan sebagai standard dasar dalam penyusunan QRIS. Standar ini digunakan untuk mendukung interkoneksi dan interoperabiltas antar penyelenggara, antar instrumen, antar negara sehingga dapat bersifat terbuka / open source (Adibah,dkk 2019).

Jenis- Jenis Mekanisme Transaksi Menggunakan QRIS

\section{Merchant Presented Mode}

Mekanisme QR Code Merchant Presented Mode .Pelanggan akan meng - scan QR Code yang telah disediakan merchant. Ada 2 bentuk QR Code Merchant Presented Mode :

\section{Statis}

\section{Karakteristik :}

- Mesin EDC akan mencetak struk pembayaran dengan terteranya juga QR Code

- Setiap transaksi dicetak dengan $Q R$ Code yang berbeda.

- Nominal pembayaran telah tertera pada $Q R$ Code.

\section{Dinamis}

\section{Karakteristik :}

- Mesin $E D C$ akan mencetak struk pembayaran dengan terteranya juga $Q R$ Code dan monitor akan menunjukan nominal pembayaran.

- Setiap transaksi dicetak dengan $Q R$ Code yang berbeda.

- Nominal pembayaran telah tertera pada $Q R$ Code.

\section{Customer Presented Mode}

Mekanisme QR Code Customer Presented Mode ini dapat digunakan oleh setiap orang. Konsumen dapat memilih dan mengunduh aplikasi pembayaran yang terpasang pada ponsel dan mempunyai saldo untuk bertransaksi.Merchant akan menscan QR Code yang ditampilkan melalui smartphone pelanggan. 


\section{Bertransaksi menggunakan QRIS}

Perangkat yang harus disediakan dalam bertransaksi dengan QRIS dibutuhkan : smartphone yang dapat meng-scan QR Code, paket data internet, aplikasi pembayaran,dan saldo pada aplikasi pembayaran.

\section{- Metode Transaksi Sebelum QRIS}

Merchant harus menyediakan beberapa aplikasi pembayaran di tokohnya. Konsumen yang membayar secara non tunai, harus memastikan bahwa aplikasi pembayaran yang dimilikinya harus tersedia pada merchant.

\section{- Metode Transaksi Setelah QRIS}

Merchant tidak perlu mempersiapkan banyak aplikasi pembayaran, hanya menyediakan satu QR Code di tokoh dan QR Code dapat di-scan oleh konsumen dengan berbagai aplikasi pembayaran di smartphone.
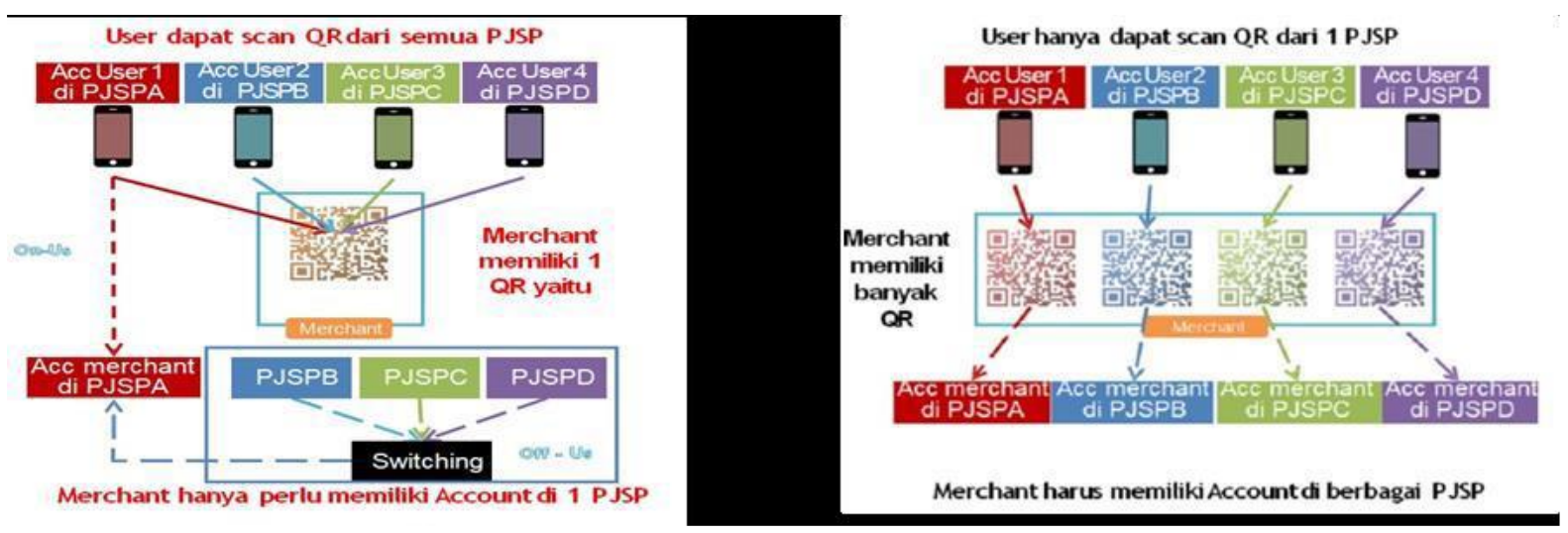

Sumber:www.bi.go.id

\section{Pengertian UMKM}

UMKM adalah sebuah usaha yang dimiliki perorangan maupun kelompok yang dinilai lewat pendapatan yang diperoleh dan jumlah banyak pekerja pada perusahaan itu. Pada UU No.20 Tahun 2008 bahwa UMKM itu harus mempunyai sebuah siklus usaha yang harus diperhatikan, asas-asas, tujuan, pemberdayaan yang terkordinasi, dan melihat sanksi administrative yang terjadi. UU No.20 Tahun 2008 juga mengkaji banyak bidang seperti pertanian, perdagangan, jasa, pengangkutan,dan bukan hanya sektor industri.

Definisi UMKM pada Undang - undang (UU) No.20 Tahun 2008 tentang Usaha Mikro, kecil,dan Menengah adalah sebuah kegiatan ekonomi yang dilakukan perorangan/ badan usaha dan bukan milik anak perusahaan ataupun cabang yang memiliki kekayaan bersih sebesar 
Rp.50 juta sampai Rp500 juta selain tanah dan tempat usaha atau memiliki pendapatan tahunan sebesar Rp 300 juta sampai Rp 2,5 miliar (Vellayati, dkk, 2013).

\section{METODE PENELITIAN}

Metode penelitian adalah pola pikir dan anggapan dasar yang dijadikan pijakan berpikir dalam melakukan penelitian. (Noor, 2017). Metode penelitian dalam penelitian ini adalah metode kualitatif, metode kualitatif dikutip dari (Noor, 2017) menurut Denzin dan Licoln (2009), kata kualitatif adalah sebuah penekanan proses yang tidak mengukur pada penekanan berupa kuantitas, dan intesitasnya. Metode wawancara menjadi teknik untuk pengumpulan data pada penelitian ini.

Dalam penelitian ini, peneliti telah mewawancarai 4 pedagang UMKM yang telah menggunakan QRIS untuk sistem pembayaran non - tunai di tokohnya. Lokasi penelitian yang dilakukan adalah Tokoh Galeri 808 di Pasar Beruang Medan, Tokoh Suwarno di Pasar Petisah Medan, Tokoh Hokita di Jalan Madong Lubis Medan, dan Rumah Makan Minang Maimbou 2 di Jalan Pukat Banting 2 Medan.Dalam pengumpulan data primer, penulis menggunakan teknik non-probability untuk pengumpulan data dan peniliti telah mempersiapakan daftar pertanyaan yang diajukan kepada informan.Selain teknik pengumpulan data dengan wawancara, peneliti juga menggunakan studi literatur dari buku, jurnal, dan sumber- sumber bacaan yang relevan untuk mendukung jurnal ini. Alat bantu yang digunakan dalam wawancara : smartphone, dan peralatan tulis.

\section{HASIL DAN PEMBAHASAN}

\section{Penggunaan Uang Elektronik Berbasis Server}

Pada penelitian yang telah dilakukan bahwa penerapan pembayaran non- tunai pada pedagang UMKM telah dilakukan.Penggunaan pembayaran transaksi non-tunai ini diterapkan karena adanya perkembangan yang pesat pada teknologi dan informasi yang harus diikuti. Bentuk pembayaran non-tunai yang telah disediakan oleh pedagang UMKM di tokohnya yaitu berbasis chip dan berbasis server. Penggunaan pembayaran berbasis server banyak digunakan oleh pedagang UMKM. Bentuk instrumen pembayaran berbasis server adalah $e$ wallet.Walaupun para pedagang UMKM masih lebih menyukai pembayaran secara tunai , tetapi menurut 4 informan pada penelitian ini mengatakan bahwa transaksi pembayaran tersebut harus diikuti dan diterapkan dalam perkembangan era digital.

Para pedagang UMKM tersebut memilih pembayaran non tunai menggunakan aplikasi $e-$ wallet di tokohnya dengan menyediakan $\mathrm{QR}$ Code. Alasan utamanya karena banyak 
pelanggan menggunakan aplikasi $e$ - wallet di smartphonenya. Beberapa produk $e-$ wallet yang menggunakan sistem QR Code telah disediakan oleh pedagang tersebut, antara lain QR Code OVO,QR Code GO-PAY, QR Code LINK AJA. Dalam proses transaksi non tunai, para pedagang sering menggunakan QR Code OVO di tokohnya, sebab pelanggan mendominasi menggunakan aplikasi tersebut.

\section{Penerapan QRIS pada UMKM}

Bank Indonesia telah meluncurkan sebuah kanal/sistem pembayaran untuk menstandarisasi seluruh pembayaran non tunai berbasis server yang menggunakan media QR Code sebagai transaksi. Sistem pembayaran tersebut adalah yaitu Quick Response Indonesia Standard (QRIS) . Penerapan QRIS ini telah dilakukan pada 1 Januari 2020 di Indonesia. Penerapan QRIS ini diutamakan terlebih dahulu kepada para pedagang UMKM.

Berdasarkan penelitian yang telah dilakukan bahwa beberapa pedagang UMKM di Medan telah menggunakan QRIS .Para pedagang UMKM sebagai narasumber penelitian ini mengatakan bahwa penerapan QRIS ini dilakukan karena keinginan para pedagang tersebut untuk mengikuti perkembangan teknologi dan informasi. Mengikuti era teknologi dan informasi akan meningkatkan kecepatan dalam melakukan aktivitas pada kehidupan kita. Oleh sebab itu , para pedagang UMKM ini terbantu dengan adanya QRIS sehingga mempercepat transaksi menggunakan QR Code.

Bentuk QRIS yang telah tersedia di tokoh para pedagang adalah bentuk statis (berbentuk stiker atau bentuk lain). Peletakan stiker QRIS tersebut diletakan di dinding tokoh, meja kasir, dan steling kaca yang dapat discan oleh pelanggan. Pelanggan yang melakukan pembayaran dengan QRIS, harus mempunyai aplikasi $e$-wallet di smartphone. Para pelanggan yang menggunakan QRIS ini didominasi oleh kalangan muda, driver online dan ada juga dari beberapa kalangan orangtua. Beberapa pedagang UMKM telah menerapkan sistem pembayaran ini di tokohnya, hanya saja penggunaannya tidak dilakukan setiap hari,tetapi dengan adanya sistem ini tidak membuat kesulitan melainkan memberikan kemudahan para pedagang di tokoh. Hasil yang didapatkan lewat wawancara bahwa adanya QRIS sangat membantu proses transaksi. Pedagang tidak perlu mempersiapkan banyak produk QR Code di tokohnya, cukup hanya menyediakan satu QRIS dapat menerima semua transaksi dari berbagai instrument pembayaran berbasis server.

Peranan QRIS ini membantu para pedagang UMKM untuk tidak tertipu pada peredaran uang palsu, mengurangi resiko pencurian uang dan mendukung pemerintah juga dalam mampu mengembangkan perekonomian digital pada wilayah tertentu.Salah satu informan pada 
penelitian ini mengatakan bahwa sebelum ada sistem pembayaran non-tunai,para pedagang UMKM mengalami kesusahan bila mengembalikan uang pelanggan yang nominalnya besar maupun kecil. Selain untuk mempermudah transaksi, sistem pembayaran QRIS membantu pedagang untuk mencatat pendapatan harian dan pedagang terbantu juga untuk melihat produk produk yang terjual secara cepat di tokoh.

Keberadaan QRIS sangat mendukung proses transaksi pedagang dan menjaga keamanan pendapatan. Meningkatnya pendapatan harian para pedagang UMKM disebabkan keberadaan QRIS. Peningkatan pendapatan yang terjadi sekitar 5-10 \% dalam sehari bagi beberapa pedagang. Selain itu ada pedagang yang mengalami kenaikan pendapatan saat hari Sabtu dan Minggu saat menggunakan QRIS. Kenaikan pendapatan ini akan meningkatkan inklusi keuangan pada pedagang UMKM dan perekonomian digital negara.

\section{Kendala QRIS terhadap UMKM}

Penggunaan QRIS ini mengalami beberapa kendala pada kalangan UMKM. Kendala tersebut disebabkan oleh penggunaan kanal pembayaran itu dan pedagang yang kurang memahami sistem kerja kanal pembayaran tersebut. Dalam penggunaan sistem pembayaran menggunakan QRIS ,para pedagang UMKM mengalami ketidakpuasan atas adanya biaya merchant discount rate( $M d r$ ) sebesar 0,6\% yang diberlakukan kepada para pedagang.Hal ini akan menyebabkan pendapatan harian pedagang akan berkurang. Kendala pada penggunaan kanal pembayaran ini yaitu pada kekuatan jaringan internet yang kurang baik di beberapa membuat proses transaksi terhambat di tokohnya. QRIS masih sulit diterapkan oleh beberapa pedagang karena kurangnya literasi yang dilakukan pada sistem tersebut.

\section{PENUTUP}

Dalam penelitiannya penulis menyimpulkan bahwa, dengan adanya Quick Response Indonesia Standard dapat membantu para pedagang UMKM untuk mengalami perkembangan. Penerapan sistem pembayaran QRIS untuk instrumen pembayaran berbasis server yang menggunakan QR Code telah dilakukan oleh beberapa pedagang UMKM di Medan. Hasil wawancara yang diperoleh, kebanyakan informan mengatakan bahwa QRIS memiliki pengaruh terhadap perkembangan UMKM. Hal ini terbukti dari cara informan menjawab pertanyaan yang diberikan. Menyediakan satu QRIS di tokoh akan dapat melayani seluruh aplikasi pembayaran yang menggunakan QR Code. Dalam penelitian ini penulis memberikan saran kepada para pedagang UMKM untuk menggantikan QR Code yang beraneka penerbit tersebut dengan QR Code yang baru yakni ; QR Code Indonesia Standard (QRIS) yang 
dikeluarkan oleh Bank Indonesia.Selain itu, pemerintah harus memperkuat keberadaan jaringan internet pada berbagai lokasi yang dominan menggunakan sistem pembayaran berbasis server. Keterbatasan penelitian ini pada kuantitas informan yang kurang memadai karena beberapa pedagang UMKM belum menerapkan QRIS di tokohnya. Penelitian ini diharapkan dapat dikembangkan lagi dengan jumlah informan dalam skala besar dan dapat menjadi bahan untuk penelitian selanjutnya. 


\section{DAFTAR PUSTAKA}

APJII. (2019). Penetrasi \& Profil Perilaku Pengguna Internet Indonesia Tahun 2018.APJII:5 Bank Indonesia.(2019). Daftar Penerbit Uang Elektronik: 2.

Arianti, N.L.N., Darma, G.S., Maradona, A.F., and Mahyuni, L.P. (2019). Menakar Keraguan Penggunaan QR Code Dalam Transaksi Bisnis, Jurnal Manajemen \& Bisnis, 16 (2): $67-78$.

BI. (2019). Transaksi Uang Elektronik di Indonesia. Databoks.

Genady, D.I. (2018). Pengaruh Kemudahan, Kemanfaatan, Dan Promosi Uang Elektronik Terhadap Keputusan Penggunaan Uang Elektronik Di Masyarakat (Studi Kasus di Provinsi DKI Jakarta). Skripsi. 11140850000042

Ministry Cooperation \& SME Republic of Indonesia.(2018). Perkembangan Data Usaha Mikro, Kecil, Menengah (UMKM) Dan Usaha Besar (UB) Perkembangan Data Usaha Mikro, Kecil, Menengah (UMKM) Dan Usaha Besar (UB). www.Depkop.Go.Id.2002(1): 2011-2012.

Mumtazah, A., Muslimah, A. Y., Rahmawati, D.F., Lea , E., Ayda, N. (2019). Server based payment system indonesia di era revolusi industry 4.0. Seminar Nasional Applied Science, Business and Information System (ASBIS) 2019 .6014(17-24).

Noor, J. (2017). Metodologi Penelitian : Skripsi, Tesis, Disertasi, dan Karya Ilmiah. Jakarta: Prenadamedia Group.

Puspita,Y.C. (2019). Analisis Kesesuaian Teknologi Penggunaan Digital Payment Pada Aplikasi Ovo, Jurnal Manajemen Informatika, 9 (2): 121-128.

Sagayarani, D. (2018). Digital Payments in India 2018-2019, IOSR Journal of Business and Management (IOSRJBM):28-33

Urfa, V.H., Handayani, S.R., Hidayat, R.R. (2013). Program Kemitraan BUMN Terhadap Kinerja UMKM (Studi Kasus Pada Program Kemitraan PT. Telekomunikasi Indonesia, Tbk Sub Area Malang Untuk Industri Sari Apel Brosem Kota Batu), Jurnal Adminstrasi Bisnis,6 (1): 1-10. 